\title{
Anthelmintic Activity of Hygrophila difformis Blume
}

\author{
Krishanu Samanta ${ }^{1}$, Emdad Hossain*,1 and Dilip Kumar Pal ${ }^{2}$ \\ ${ }^{1}$ Pharmacy College, Azamgarh, Uttar Pradesh 276128, India \\ ${ }^{2}$ School of Pharmaceutical Sciences, IFTM University, Moradabad 244001, Uttar Pradesh, India
}

\begin{abstract}
This study evaluated the anthelmintic activity of the petroleum ether, benzene, chloroform, ethanol extracts of aerial parts of Hygrophila difformis (Family: Acanthaceae). The Pheretima posthuma were used for all the experimental protocol due to their anatomical and physiological resemblance with the intestinal roundworms of ruminants and human beings. The worms were treated with the extract solutions containing three different concentrations $(10,25$ and 30 $\mathrm{mg} / \mathrm{ml}$ ), for each extracts supplemented with $1 \%$ gum acacia in normal saline at $37 \pm 1^{\circ} \mathrm{C}$. Albendazole at a dose of 10 $\mathrm{mg} / \mathrm{ml}$ was used as reference. The effectiveness of the extracts was judged on the basis of the loss of spontaneous movement and/or death of the worms. Qualitative phytochemical analysis of different extracts of the plant was carried out following the standard procedure. All extracts at different dose levels effectively paralyzed and killed the worm in dose-dependent fashion $(p<0.001)$. Maximum anthelmintic activity was found with benzene extract. Cardiac glycosides, tannins, steroids, flavonoids and saponins were found positive in phytochemical analysis. The present study established the anthelmintic activity of $H$. difformis and can be utilized for the ruminants.
\end{abstract}

Keywords: Anthelmintic, benzene extract, cardiac glycoside, Hygrophila difformis, Cardanthera triflora, Pheretima posthuma, phytochemical analysis, steroid.

\section{INTRODUCTION}

Helminths produce severe problem in animals, birds, fishes and human beings round the world. Although, in most occasions, helminth infections are in asymptomatic state and seems to be not so serious, but in heavily infected human or animals, they become responsible for severe morbidity. Helminthic infections may subvert immune responses to pathogens of other diseases through suppression of the immune response [1].

Paramphistomes (Superfamily: Paramphistomoidea) are responsible for paramphistomosis, is characterized by acute parasitic gastroenteritis with high morbidity and mortality rates, especially in young stock [2-3]. Fasciola hepatica is well known as liver-fluke, responsible for fascioliasis in humans and ruminants in temperate regions of the world including Bolivia, Chile, Cuba, Ecuador, Egypt, France, Peru, Portugal, Spain, Vietnam etc. [4-5]. The flatworm damages liver parenchyma and bile ducts of its host like sheep, cow, buffalo, man, may be responsible for death of the host [6-7]. Haemonchus contortus, a gastrointestinal nematode, is also responsible for large economic losses to livestock breeders by causing appetite depression, damages in gastric function [8]. Planaria and Rhipicephalus microplus (Canestrini, 1887) produces a serious problem for the cattle industry in tropical and subtropical regions of the world [9-10].

*Address corresponding to this author at the Pharmacy College, Azamgarh, Uttar Pradesh 276128, India; Tel: +91-9450385946; Fax:+91-5462-243134; E-mail: hossainemdad@yahoo.com
Triclabendazole, Ivermectin, levamisole, diamphenethide, albendazole, rafoxanide and other popular synthetic anthelmintic drugs were used against different parasitic infections. However, resistance in ruminants and human has been developing and is spreading in tropic and subtropic countries [11-12].

Anthelmintics obtained from medicinal plants can be utilized for the treatment of parasitic infections effectively [13]. Several plants including Alpinia nigra, Anogeissus leiocarpus, Dregea volubilis, Ficus benghalensis, Flemingia vestita, Piper sp., Zanthoxylum rhetsa have been tested for their anthelmintic efficacy [10, 14-19].

Hygrophila difformis (L.f.) Blume (Family: Acanthaceae) \{Cardanthera triflora Buch.-Ham. Ex Benth\}, commonly known as water wisteria, is a tropical aquarium plant used as environmental ornaments. It is found in marshy habitats on the Indian subcontinent including Bangladesh, Bhutan and Nepal. The plant is used as coagulant by different tribal people in India [20]. Hygrophiloside was found on preliminary chemical analysis of the aerial parts of Hygrophila difformis [21]. CNS depression activity was found with the aerial part of the plant [22]. No report was found regarding anthelmintic activity of $H$. difformis till the date.

The purpose of the present work was to investigate the anthelmintic activity of a different extract of the aerial parts of Hygrophila difformis. 


\section{MATERIAL AND METHODS}

\section{Plant Material}

Aerial parts of $H$. difformis were collected from fields of Kanakpur, District of East Midnapur, West Bengal, India in the month of December and authenticated by Dr. M.S. Mondal, a taxonomist and Additional Director, Central National Herbarium, Botanical Survey of India, Howrah, West Bengal, India. A voucher specimen has been preserved in Department of Pharmaceutical Chemistry, Seemanta Institute of Pharmaceutical Science, Jharpokharia, Orissa, India for future reference (Voucher specimen no. $\mathrm{CNH} / 1-\mathrm{I}$ (315)/2009-Tech II/357). The aerial parts were dried under shade and powdered (40 mesh size) and stored in airtight containers.

\section{Preparation of Extract}

The powdered plant material was extracted with petroleum ether $\left(40-60^{\circ} \mathrm{C}\right)$ and the merc was successively extracted with benzene, chloroform, ethanol respectively in a series using a Soxhlet extractor. The extracts were concentrated to dryness under vacuum individually to get petroleum ether extract (PEHD), benzene extract (BEHD), chloroform extract (CEHD), ethanol extract (EEHD) respectively. The yield of petroleum ether, benzene, chloroform and ethanol extracts were $4.26,3.25,1.85,9.17 \% \mathrm{w} / \mathrm{w}$ respectively. The prepared extracts were tested for anthelmintic activity and qualitative phytochemical analysis.

\section{Test Organism}

The earthworms (Pheretima posthuma) were used for all the experimental protocol due to their anatomical and physiological resemblance with the intestinal roundworm parasites of human beings and other ruminants [23-26]. Indian adult earthworms $(12-15 \mathrm{~cm}$ in length and $0.3-0.5 \mathrm{~cm}$ in width) collected from moist soil and washed with normal saline $(0.9 \% \mathrm{w} / \mathrm{v}$, aqueous sodium chloride) to remove all unnecessary matter, were used for the anthelmintic study.

\section{Anthelmintic Activity}

The Anthelmintic activity of aerial parts of Hygrophila difformis extracts was determined by using the method described by Nirmal et al. [27] with slide modification. Briefly, worms were placed in Petri dishes containing $20 \mathrm{ml}$ of the extract solution having three different concentrations $(10,25$ and $30 \mathrm{mg} / \mathrm{ml})$, each of petroleum ether (PEHD), benzene (BEHD), chloroform (CEHD) and ethanol extract (EEHD) respectively supplemented with $1 \%$ gum acacia in normal saline at $37 \pm 1{ }^{\circ} \mathrm{C}$. Albendazole $(10 \mathrm{mg} / \mathrm{ml})$ was used as reference standard (positive control) while 1\% gum acacia in normal saline as negative control [28-30]. Six set of experiments was done for each concentration. The time taken to paralyze and kill individual worms was observed. Paralysis was noted when the worms become immobile even in the normal saline solution. Death was concluded when the worms lost their motility even when vigorously shaken or dipped in warm water followed by fading away of their body color.

\section{Phytochemical Analysis of the Plant Extracts}

Qualitative phytochemical analysis of different extracts of the plant was carried out by established methodologies in search of active ingredient responsible for anthelmintic study. The phytochemicals included under study were alkaloids, cardiac glycosides, tannins, steroids, flavonoids and saponins, were carried out according to the methodologies of Harborne [31] and Khandelwal [32].

\section{Statistical Analysis}

All results were expressed as mean \pm S.E.M and analyzed for statistical significance by one-way analysis of variance (ANOVA) followed by Tukey test using computerized GraphPad Prism version 4.03, Graph Pad Software Inc. $p<0.05$ was considered as statistically significant.

\section{RESULTS AND DISCUSSION}

Different extracts of aerial part of Hygrophila difformis at different dose levels effectively paralyzed and killed the earthworms $(p<0.001)$ (Table 1). In all cases the efficacy was in dose-dependent fashion i.e. the efficacy of the extract gradually reduced with reduction of the dose. Among all the extracts, the benzene extract (BEHD) was found to be most effective for paralyzing as well as for killing the worms and petroleum ether extract is having least anthelmintic activity. Maximum activity was found at dose of 30 $\mathrm{mg} / \mathrm{ml}$. Ethanol extract (EEHD) also showed significant activity $(p<0.001)$ but slight less than the benzene extract. Albendazole took moderate time for paralysis $(37.17 \pm 2.04 \mathrm{~min})$ or death $(65.50 \pm 1.84 \mathrm{~min})$ for the worms $(p<0.001)$ (Table 1). Worms incubated in control media showed spontaneous physical activities for more than 24 hours. 
Table 1: Anthelmintic Activity of Hygrophila difformis

\begin{tabular}{|c|c|c|c|}
\hline Treatment & Conc. $(\mathrm{mg} / \mathrm{ml})$ & Paralysis time (min) & Death time (min) \\
\hline Control & - & - & - \\
\hline Albendazole & 10 & $37.17 \pm 2.04^{* * *}$ & $65.50 \pm 1.84^{* * *}$ \\
\hline Petroleum ether extract (PEHD) & $\begin{array}{l}10 \\
25 \\
30\end{array}$ & $\begin{array}{l}56.17 \pm 2.02^{\star \star \star} \\
27.17 \pm 1.78^{\star \star *} \\
26.33 \pm 0.84^{\star \star *}\end{array}$ & $\begin{array}{c}135.00 \pm 1.86^{\star * \star} \\
69.33 \pm 1.89^{\star * *} \\
67.17 \pm 1.05^{\star * *}\end{array}$ \\
\hline Benzene extract (BEHD) & $\begin{array}{l}10 \\
25 \\
30\end{array}$ & $\begin{array}{l}25.17 \pm 1.80^{\star \star *} \\
15.17 \pm 1.49^{\star \star *} \\
13.17 \pm 1.22^{\star \star \star}\end{array}$ & $\begin{array}{l}36.50 \pm 3.02^{\star * \star} \\
28.17 \pm 1.92^{\star * \star} \\
25.83 \pm 1.96^{\star \star *}\end{array}$ \\
\hline Chloroform extract (CEHD) & $\begin{array}{l}10 \\
25 \\
30\end{array}$ & $\begin{array}{l}62.17 \pm 2.57^{* * *} \\
29.33 \pm 1.26^{\star * *} \\
27.17 \pm 0.91^{* * *}\end{array}$ & $\begin{array}{c}118.33 \pm 1.17^{\star * *} \\
56.50 \pm 2.39^{\star * *} \\
54.50 \pm 1.29^{\star * *}\end{array}$ \\
\hline Ethanol extract (EEHD) & $\begin{array}{l}10 \\
25 \\
30\end{array}$ & $\begin{array}{l}40.33 \pm 1.23^{* * *} \\
30.83 \pm 1.87^{* * *} \\
25.00 \pm 1.81^{* * *}\end{array}$ & $\begin{array}{l}70.50 \pm 1.80^{\star * *} \\
62.33 \pm 2.29^{\star \star *} \\
56.33 \pm 2.80^{\star * *}\end{array}$ \\
\hline
\end{tabular}

${ }^{\#}$ Data are expressed as the mean of results in 6 set \pm S.E.M. ${ }^{* * *} p<0.001$.

Table 2: Qualitative Analysis of Various Extracts of Hygrophila difformis

\begin{tabular}{|c|c|c|c|c|c|}
\hline S. No. & Test & Pet. ether extract & Benzene extract & Chloroform extract & Ethanol extract \\
\hline \hline 1 & Alkaloids & - & - & - & - \\
\hline 2 & Cardiac glycosides & + & + & + & + \\
\hline 3 & Tannins & - & - & + & + \\
\hline 4 & Steroids & + & - & + \\
\hline 5 & Flavonoids & - & - & - \\
\hline 6 & Saponins & - & & + \\
\hline
\end{tabular}

$(+)$ - present, (-)-absent.

Preliminary phytochemical screening revealed the presence of cardiac glycosides, tannins, steroids, flavonoids and saponins for different extracts as mentioned in Table 2.

In this in vitro study, the effectiveness of the extract had been judged on the basis of the loss of spontaneous movement and/or death of the worms [18]. As shown in the Table 1, the benzene extract of $H$. difformis displayed a significant anthelmintic property in a dose dependent manner giving shortest time of paralysis and death with $30 \mathrm{mg} / \mathrm{ml}$ concentrations, comparable with the standard drug albendazole. The ethanol and chloroform extracts exhibited a modest activity.

Phytochemical analysis of the crude extract revealed presence of steroids and cardiac glycosides as the key phytoconstituents in all extracts. In theoretical studies steroids and cardiac glycosides were shown to produce anthelmintic activities [16, 3335]. It can be predictable that the activity is due to the above secondary metabolite and the difference efficacies of the different extract may be due to quantitative variation of the steroids and cardiac glycosides. In our earlier studies, ethanol extract (EEHD) is a safe drug and no mortality was observed up to $2.5 \mathrm{~g} / \mathrm{kg}$, intra-peritoneally (i.p.) in acute toxicity tests in mice [22]. It can be expected that the extracts are safe to a large dose in oral form to the ruminants.

From the results obtained in this present study, it is clear that the petroleum ether, benzene, chloroform, ethanol extracts of aerial parts of Hygrophila difformis possess anthelmintic activity.

\section{REFERENCES}

[1] Brown M. Intestinal helminths. Medicine 2005; 33: 54-7. http://dx.doi.org/10.1383/medc.2005.33.8.54

[2] Panyarachun B, Sobhon P, Tinikul Y, Chotwiwatthanakun C, Anupunpisit V, Anuracpreeda P. Paramphistomum cervi: Surface topography of the tegument of adult fluke. Exp Parasitol 2010; 125: 95-9.

http://dx.doi.org/10.1016/j.exppara.2009.12.020 
[3] Rolfe PF, Boray JC. Chemotherapy of paramphistornosis in sheep.. Australian Vet J 1988; 65: 148-50. http://dx.doi.org/10.1111/j.1751-0813.1988.tb14443.x

[4] Kirchhofer C, Vargas M, Braissant $O$, et al. Activity of OZ78 analogues against Fasciola hepatica and Echinostoma caproni. Acta Tropica 2011; 118: 56-62.

http://dx.doi.org/10.1016/j.actatropica.2011.02.003

[5] Nguyen TGT, Le TH, Dao THT, et al. Bovine fasciolosis in the human fasciolosis hyperendemic Binh Dinh province in Central Vietnam. Acta Tropica 2011; 117: 19-22.

http://dx.doi.org/10.1016/j.actatropica.2010.09.003

[6] Milligen FJV, Cornelissen JBWJ, Gaasenbeek CPH, Bokhout BA. A novel ex vivo rat infection model to study protective immunity against Fasciola hepatica at the gut level. J Immunol Methods 1998; 213: 183-90.

[7] Keiser J, Morson G. Fasciola hepatica: Fasciola hepatica: Surface tegumental responses to in vitro and in vivo treatment with the experimental fasciolicide OZ78. Exp Parasitol 2008; 119: 87-93.

http://dx.doi.org/10.1016/j.exppara.2007.12.015

[8] Fox MT. Pathophysiology of infection with Ostertagia ostertagi in cattle. Vet Parasitol 1993; 46: 143-58. http://dx.doi.org/10.1016/0304-4017(93)90055-R

[9] Lal SS. A text book of practical zoology invertebrate, $9^{\text {th }}$ ed. Meerut: Rastogi Publications; 2006.

[10] Ferraz ABF, Balbino JM, Zini CA, Ribeiro VLS, Bordignon SAL, Poser GV. Acaricidal activity and chemical composition of the essential oil from three Piper species. Parasitol Res 2010; 107: 243-8.

[11] Fairweather I, Boray JC. Fasciolicides: Efficacy, actions, resistance and its management. Vet J 1999; 158: 81-112. http://dx.doi.org/10.1053/tvjl.1999.0377

[12] Kaewintajuk K, Cho PY, Kim SY, et al. Anthelmintic activity of KSI-4088 against Caenorhabditis elegans. Parasitol Res 2010; 107: 27-30.

http://dx.doi.org/10.1007/s00436-010-1828-8

[13] Carvalho CO, Chagas ACS, Cotinguiba F, et al. The anthelmintic effect of plant extracts on Haemonchus contortus and Strongyloides venezuelensis. Vet Parasitol 2012; 183: 260-8.

http://dx.doi.org/10.1016/j.vetpar.2011.07.051

[14] Agaie BM, Onyeyili PA. Anthelmintic activity of the crude aqueous leaf extracts of Anogeissus leiocarpus in sheep. Afr J Biotech 2007; 6: 1511-5.

[15] Aswar M, Aswar U, Watkar B, Vyas M, Wagh A, Gujar KN. Anthelmintic activity of Ficus benghalensis. Int J Green Phar 2008; 2: 170-2.

http://dx.doi.org/10.4103/0973-8258.42737

[16] Hossain E, Chandra G, Nandy AP, Mandal SC, Gupta JK. Anthelmintic effect of a methanol extract of leaves of Dregea volubilis on Paramphistomum explanatum. Parasitol Res 2012; 110: 809-14.

http://dx.doi.org/10.1007/s00436-011-2558-2

[17] Roy B, Swargiary A. Anthelmintic efficacy of ethanolic shoot extract of Alpinia nigra on tegumental enzymes of Fasciolopsis buski, a giant intestinal parasite. J Parasit Dis 2009; 33: 48-53.

http://dx.doi.org/10.1007/s12639-009-0008-1

[18] Tandon V, Pal P, Roy B, Rao HSP, Reddy KS. In vitro anthelmintic activity of root-tuber extract of Flemingia vestita, an indigenous plant in Shillong, India. Parasitol Res 1997;
83: 492-8.

http://dx.doi.org/10.1007/s004360050286

[19] Yadav AK, Tangpu V. Therapeutic efficacy of Zanthoxylum rhetsa DC extract against experimental Hymenolepis diminuta (Cestoda) infections in rats. J Parasit Dis 2009; 33: 42-7. http://dx.doi.org/10.1007/s12639-009-0007-2

[20] Fosberg FR, Sachet MH. Identity and typification of Rubellia triflora Roxb. and Rubellia difformis L.F. (Acanthaceae). Baileya 1984; 22: 138-40.

[21] Jensen SR, Nielsen BJ. Hygrophiloside, an iridoid glucoside from Hygrophila difformis (Acanthaceae). Phytochem 1985; 24: $602-3$ http://dx.doi.org/10.1016/S0031-9422(00)80778-5

[22] Pal DK, Samanta K. CNS activities of ethanol extract of aerial parts of Hygrophila difformis in mice. Acta Poloniac Pharmaceutica-Drug Res 2011; 68: 75-81.

[23] Thorn GW, Adams RD, Braunwald E, Isselbacher KJ, Petersdrof RG. Harrison's Principles of Internal Medicine, New York: Mcgraw Hill Co. 1977.

[24] Vigar Z. Atlas of Medical Parasitology. $2^{\text {nd }}$ ed. Singapore: P.G. Publishing House 1984.

[25] Vidyadhar S, Saidulu M, Gopal TK, Chamundeeswari D, Rao $\mathrm{U}$, Banji D. In vitro anthelmintic activity of the whole plant of Enicostemma littorale by using various extracts. Int J Applied Biol Pharmac Tech 2010; 1: 1119-5.

[26] Parmar S, Kesarwala M, Parekh Z, Shah K, Shah N, Patel P. Comparative studies on anthelmintic activity of Butea monosperma and Adhatoda zeylanica leaf extract. Int J Pharm Res Dev 2011; 3: 102-105.

[27] Nirmal SA, Malwadkar G, Laware RB. Anthelmintic activity of Pongamia glabra. Songklanakarin J Sci Technol 2007; 29: 755-7.

[28] Suman A, Kumar DG, Kumar BD, Raj CR. Preliminary phytochemical investigation and anthelmintic activity of Acacia suma (Roxb) barks. Int Res J Phar 2011; 2: 136-41.

[29] llango K, Xavier AR, Subburaju T. Anthelmintic activity of extracts of aerial parts of Tephrosia spinosa (L.f.) Pres. Int $J$ Health Res 2011; 4: 53-56.

http://dx.doi.org/10.4314/ijhr.v4i1.70436

[30] Roy H, Chakraborty A, Bhanja S, Nayak BS, Mishra SR, Ellaiah P. Preliminary phytochemical investigation and anthelmintic activity of Acanthospermum hispidum DC. J Pharm Sci Tech 2010; 2: 217-221.

[31] Harborne JB. Phytochemical methods, a guide to modern techniques of plant analysis. London: Chapman and Hall 1984.

[32] Khandelwal KR. Practical Pharmacognosy. Pune: Nirali Prakashan 2006.

[33] Sarojini N, Manjari SA, Kant CC. Phytochemical screening and anthelmintic activity study of Saraca indica leaves extracts. Int Res J Pharm 2011; 2: 194-7.

[34] Vincent S, Vijayamirtharaj R, Wilson P, Saravanan B, Jeevanatham P, Ramesh R. Anthelmintic potential of aerial part of Clerodendrum phlomidis linn. Res J Pharm Biol Chem Sci 2011; 2: 329-33.

[35] Akhtar MS, Iqbal Z, Khan MN. Evaluation of anthelmintic activity of Chenopodium album (Bathu) against nematodes in sheep. Int J Agri Biol 1999; 1: 121-4. 